\title{
Tendencies of overcoming crises in the housing-and-communal sphere: international aspect
}

\author{
Oksana Skrypnik ${ }^{1, *}$ \\ ${ }^{1}$ Moscow State University of Civil Engineering, Yaroslavskoe shosse, 26, Moscow, 129337, Russia
}

\begin{abstract}
In the condition of market economy in the housing sphere it is accepted to differentiate two interacting markets - the market of housing stock and the market of housing services. The beginning of market grouping of the housing stock as basic element of the real estate market in Russia, it was necessary in 1991 by adoption of legal acts for privatization of housing. After that the market of housing services began to be arranged. The historical development of the housing market can be considered through the system of institutional changes with respect to the development of the economy and enhancement of the infrastructure. Institutes represent the rules, mechanisms providing their accomplishment, and standards of behavior which structure the repeating interactions among citizens. It becomes obvious that the institutes determine and limit the set of alternatives which are available for each economic actor, they include all forms of the restrictions created by people to give a certain structure to human relations. However it is also important to understand that institutes, being standard restrictions, create opportunities which members of the society have, thanks to the fact that the same institutes reduce uncertainty, structuring activities of individuals. The set of the formal and informal institutes created in economy represents the institutional environment. As a result the institutes perform functions of so called first and second order. Functions of the first order have specific character and solve specific objectives which are the cornerstone of rules: coordination, cooperation and distribution. The institutional environment performs the functions of the second order, which are aimed on market regulation, ensuring predictability and stability, safety, minimization of costs for transactions and training. In this article the main directions, conditions and approaches of transformations in the housing market are revealed. Forming of the structure and the environment of the housing market in the form of publicand-private partnership is analyzed. The marketing role in implementation of interaction between subjects of the housing market is revealed.
\end{abstract}

\section{Introduction}

It is also important to understand that institutes, being standard restrictions, create the opportunities which members of society have, thanks to the fact that the same institutes

\footnotetext{
*Corresponding author: rn07@yandex.ru
} 
reduce the uncertainty, structuring activities of individuals. That is from the point of view of neo-institutsionalist the main function of institutes as elements of the economic system [1]. The set of the formal and informal institutes created in the economy represents the institutional environment. As the result institutes perform functions of the first and second order. Functions of the first order have specific character and solve specific objectives which are the cornerstone of rules: coordination, cooperation and distribution. The institutional environment performs the functions of the second order aimed on the market regulation, ensuring predictability and stability, safety, minimization of costs for transactions and training $[2,3]$.

The institutes which are the crucial elements of institutional system remain, updated and change, i.e. they pass a normal way of development. At the same time the informal institutes which are often internal installations of economic actors and change extremely slowly, constitute as if an inside layer of institutional system, and formal institutes which can influenced by external forces create its external layer [4-12] (Table 1).

Table 1. Frequency of changes of the elements of institutional system.

\begin{tabular}{|l|l|l|}
\hline \multicolumn{1}{|c|}{ Level } & $\begin{array}{c}\text { Frequency of } \\
\text { changes }\end{array}$ & \multicolumn{1}{c|}{ Purpose } \\
\hline $\begin{array}{l}\text { Social rootedness: informal } \\
\text { institutes, customs, tradition, } \\
\text { norms, religion }\end{array}$ & $100-1000$ years & Not estimated, spontaneous \\
\hline $\begin{array}{l}\text { Institutional environment: formal } \\
\text { rules, especially property rights }\end{array}$ & $10-100$ years & $\begin{array}{l}\text { Creation of the institutional } \\
\text { environment, solution of the efficiency } \\
\text { problem }\end{array}$ \\
\hline $\begin{array}{l}\text { Mechanisms of management of } \\
\text { transactions, contracts }\end{array}$ & $1-10$ years & $\begin{array}{l}\text { Creation of the controlling mechanism } \\
\text { for transactions, solution of the } \\
\text { efficiency problem }\end{array}$ \\
\hline $\begin{array}{l}\text { Allocation of resources and } \\
\text { employment }\end{array}$ & continuous & $\begin{array}{l}\text { Determination of the correct limiting } \\
\text { conditions, solution of the efficiency } \\
\text { problem }\end{array}$ \\
\hline
\end{tabular}

The essence of institutional transformations consists in the change of elements of institutional system which can be performed by legal coercion from the state (on the centralized basis) or with active participation from the economic agents (on the decentralized basis).

\section{Methods}

The purpose of institutional transformations is the minimization of transactional expenses and the problem resolution of outer effects.

The same purposes are set in case of institutional transformations in the housing market. Within the evolution of views of institutional transformations in the housing sphere of the Russian Federation it is possible to allocate two stages. The first stage is connected with the implementation of concepts and programmes of economic reforms before August, 1998 with compliance with which the institutional transformations were considered as demonopolization of natural monopolies and carrying out market reforms in housing and public utilities. Crisis of 1998 finished the period of reforming and gave it an assessment [13]. The second stage in the evolution of views of institutional transformations assumes the integrated approach to their implementation. The complexity implies the interaction of all the participants of the housing sphere [10]. From the economic point of view, this interaction of both private, and public sector in the housing sphere is reasonable as they traditionally pursue different aims which thus should be bring together: the state is connected with the social needs, the private sector with profitability and efficiency. 
Distinctions in the level of economic development, industrialization and innovation of the economic system predetermined several scientific and methodical approaches of a system transformation of the housing sphere: French-Scandinavian (Dutch) approach and Anglo-American.

System of goal management (the French-Scandinavian Dutch approach) is based on the combination of economic, organizational and administrative and legal methods. Such a combination was aimed on forming of the competitive beginnings in the housing sector and the expansion of the circle of participants of economic process. The basis of economic relations in this system is constituted by contractual commitments on the competitive beginnings. At the same time the state participation is becoming selective, but is not ignored absolutely.

\section{Results}

The system of the market regulation of housing was firstly developed and realized in USA. It is based on the quick transition to transfer of initiatives of revival and servicing of the housing stock to hands of private companies so that the housing sphere attracted cash flows from the world and domestic capital markets under for the projects, which have exclusively market incentives. Intervention of the state in these projects should be minimum and is justified only in the relation to households with low income (improvements of quality of housing for them in case of the decrease in its cost value).

Therefore, the determined options differ in forming of the different institutional structures of the housing market mediating interaction of the state and non-state, private organizations and causing its effective functioning from the point of view of the result compliance (quality and quantity) and expenses (financial, temporary and personnel).

Опыт институциональных преобразований в Нидерландах представляет наибольший интерес, так как, по мнению многих авторов, условия развития российской экономики соответствуют условиям внедрения данной жилищной системы.

In the Netherlands three tasks on which the institutional transformations were based on the housing market were determined:

1. to care and provide the population with the necessary housing;

2. protection of acceptable quality of social housing (there was a change of the concept of quality of housing which includes the concept "made habitable the residential district");

3. availability of housing.

In the beginning of the 2000ths 763 housing corporations owned more than $1 / 3$ of the total housing stocks in the Netherlands (2.3 million dwellings) while 60 housing organizations of municipalities - only owned 33 thousand ones. 3-5 in the city of average size, 17 corporations act in Amsterdam - 17 [14]. Concerns did not come true and the private organizations will inevitably turn into commercial structures and will use budgetary funds for their enrichment. The central Government controls their activities and annually requires the report on its major directions such as:

- provision the needy people, disabled people, refugees and other target groups with housing;

- quality of new construction, repair and content of the housing stock and residential environment;

- involvement of inhabitants to the development of policy and management of housing,

- keeping the financial policy.

Work of the housing organizations includes construction, management, placement, sale, servicing of residents and improvement. Permission usually allows the organizations to work within one municipality. This municipality sends the subsidies, and also plays its 
important role during control over the housing organization. Nevertheless, the increasing number of the housing organizations works at the territory of several municipalities, often performing larger merges, and applies for permission to region level.

It is logical that in connection with strengthening of a role of corporations, the role of the government was reduced and its activities became the more and more selective.

Socially important programs in the housing sphere exists a little, but the biggest and constantly increasing article of housing expenses of the government are individual housing benefits, this system gained distribution under the Law "About Housing Benefits" in 1997. By the provision of subsidies the available property is considered. Housing benefits are allocated at the according the amount on which the market rent exceeds standard. In 1995 $14.1 \%$ of all the households in Netherlands received individual housing benefits.

In general management of housing in Netherlands represents the complex system in which separate decisions are made at various levels, presented by the state and the private sector.

The central Government determines the policy of housing construction in general, pointing the main moments by which all the subordinate levels during protection of their own interests are to be guided.

At the level of provincial authorities (12 provinces) regional space plans which define location of new housing construction are developed. Then the municipalities are guided by them by drawing up plans of zoning.

Most municipalities only own the territories of roads, squares and parks. Therefore any town-planning projects begin with the redemption by the municipality of the earth from the private owner, its engineering training, the equipment under construction and the subsequent sale or delivery to builder in long-term lease.

The municipality rather freely disposes of the budget grants arriving from the center. The administration of the large cities (with the population more than 30 thousand people) has the right to solve, where to allocate the received funds: on provision of housing for the population with the smaller income or on stimulation of a construction of private housing for own accommodation of owners. For covering of the expenses connected with development of the adverse territories, or on rent decrease in the central reconstructed regions. Small municipalities submit to more strict rules of an expenditure of means and often create intermunicipal groups for increase in the financial opportunities [6].

The municipality holds one of efficient tools in implementation of housing policies registration of needy persons and provision them with social housing. According to requirements of the municipal law the city authorities have the right to establish the quality standards and the number of social housing. They will distribute it on the basis of announcements in the special free newspaper publishing the short information about all the subsidized houses and apartments which came to the local market.

Housing corporations work according to some principles:

1. to use the profit earned for loan granting to less successful corporations;

2. has no right to use funds for construction of mainly expensive housing;

3. to develop the annual plan of actions answering to the municipal policy in advance.

Actions of housing corporations are adjusted not only "from above", but also "from below" by the public organizations uniting separate national groups on social and demographic features. Large private house owners (the pension funds, insurance companies, banks) act as owners of better and expensive housing. The role of inhabitants is constantly stimulated with the government

Thus, institutes which are the participants of housing system in Netherlands strengthen and develop the market section. Institutional transformations in the Dutch management of housing were based on the principle that the housing enterprise begins to operate on the market principles for what creates a private property on the earth and housing. It gives 
some advantage in acquisition of economic independence which once provided the industry of Netherlands with necessary degree of independence in the market conditions for the achievement of cost efficiency and the solution of the social problem of provision of housing in due time. Besides, newly created managing business companies conducted complex activities: they were engaged not only in designing and construction, but also in after-sale service during maintenance. That is the great advantage affected cost efficiency.

The experience of the solution of a housing problem and reproduction of the housing stock in Netherlands combines high market efficiency and social security of interests of the majority of its population [4,5]. And also the state regulation and encouragement of the private initiative; large-scale social and town-planning experimenting and respect for interests of own household.

In practice the application of the Dutch experience of management of housing in Russia passes the first two stages, where the responsibility laid down on shoulders of local authorities, and starts the implementation of the third with direct assistance of the private housing companies. Such methodological approach can be explained with two reasons:

1. in case of similarity of the conditions of the housing sphere in Holland in 1901 and modern in Russia, the economic, financial and social spheres which are directly connected with housing system are at higher level of the development that allows to solve housing problem more effectively.

2. the impossibility of the state independently to remove housing from the decline neither in the matter of quantity of units of housing, nor in the matter of their quality became one of incentives to housing reform in Russia.

Then the aim of creation of the developed institute of lease is pursued. Thus, it is necessary to create not only the stable increase in the housing stock, but also the funding mechanism. The activity of the housing sphere will be reached in case of reforming implementation of the tasks, which according to this classification of the system of reforming can be designated as the following priorities:

- ensuring steady resource provision of a housing complex due to attraction of the centralized and decentralized financing sources, as well as the development of material and technical resources and improvement of system of training;

- implementation of economic incentives of the improvement of quality of works and services in the housing sphere;

- the most complete ensuring accounting of interests of the population in the solution of matters of development of the housing sector;

- development of economically rational system of relations among the participants of the economic process on the legal basis [10].

In this case we will solve the social problem of the lack of quantity and quality of housing and we will make the housing industry effective from the economic point of view. In case of such concept the model of effective management lifts the relevance of institutional transformations of the housing organizations which will reflect forming of modern controlling mechanisms of the cost reduction (including financial) for provision of housing-and-communal services.

Thus, the housing system will represent the following:

Owners of the housing stock. Their fundamental role is the single social-and-financial policy in the housing sector: one standard production requirements, principles of distribution of types of resources, calculation of rates of compensation for the, priority directions of development of housing and public utilities and so on. The commitment to these principles will allow the housing sphere to develop in the complex, and will promote in many respects cost reduction of time and finance. It is important that all the decisions were made by owners of a housing stock in coordination and not for long. The organization, which plays the role of the owner of the residential room should work in the conditions of 
similar to the citizen-owner and to fulfill the financial liabilities of three types: first, to pay a tax on an property (further - the real estate tax), secondly, to constrain it, to make the current capital repairs, etc., thirdly, to pay utilities upon;

- Managing organizations (their role can be played by services of the customer).Management of technical and business assets, can be performed, including, those obtained by the services of the customer on the competitive basis;

- Contract organizations (construction and operating). They are also selected on the competitive basis and fulfil some service functions,

- Control facility. It should be provided in relative majority by the authorities since the state in case of new housing system plays the role of the esurer for all the other participants of the housing process. However not to cause any bureaucracy and corruption at this level and objectively to protect the interests of other participants, the control facility must include representatives of housing owners and consumers.

- Consumers.

State policy plays the link role between housing organizations and residents in the system of transformation of the housing sphere. Therefore its task - to protect interests of all the parties and whenever possible to stimulate their interest in interaction

The key role of the state in the housing sphere is a little one:

1. expansion of liberty of choice of citizens. It is possible thanks to: financial opportunities of people, offer of housing, participation of residents in development of housing policies;

2. institutional structure of housing policy management;

3. attention to social needs. But to protect collective values (social justice, safety, health, the favorable environment of housing, protection of the nature, pure, support of the state intermediate), the liberty of choice of people (point 1) will be always limited;

4. government and controlled market forces the Party of the Government and market interact together for the implementation of housing policies. To protect poor social groups in the housing market, market forces should be controlled and, if necessary, be regulated,

5. besides, the most important function of the Government is the increase in market transparency and elimination of excessive rules and restrictions.

The main purpose of institutional transformations in the housing market consists in demonopolization of services and formation of the market of housing services $[9,17]$. The economic basis as the base of institutional transformations must be prepared as the institutional base and infrastructure of market reforms is the valuable, economical and legal and organizational basis to market transformations and reforms should be for this purpose most well prepared. The economic basis should contain the following elements: target financing of the specific directions and projects, the fixed mechanism of creation and performance of economic agreements, orders and contracts, system of taxes, payments, soft credits and the approved rates, due legal support of economic processes that is the perhaps most effective both for the state and for the supplier and/or the consumer of housing and communal services to implement through system of public-and-private partnership.

The need of development of partnership in the market of housing-and-communal services is caused by the factors at macro-, micro- and meso- levels of economic processes. In modern conditions attraction of additional financial resources for the solution of complex problems of functioning and development of municipal system, stimulation of investments into upgrade of infrastructure becomes an urgent problem.

The main aim of partnership of the state and private sector is the expansion of space for free movement of production factors, for example, of penetration of the capital into the spheres, which were earlier unavailable for it. The public-and-private partnership represents institutional and organizational alliance between the state and private business for the 
purpose of projects implementation in various fields of activity, including ensuring public services. Using such a partnership, the state carries out one of the major functions connected with forming of the institutional environment $[8,16]$.

The public-and-private partnership is used for the implementation some other purposes: the solution of financial problems, the mechanism of increase in competitiveness in the market of private investments; instrument of public administration; implementation of the principles of corporate social liability; communication of successfully developing regional centers to improve a capability to development; method of upgrade of infrastructure; improvement of quality of public sector $[7,18]$.

\section{Discussion}

It is necessary to distinguish the following problems of financing of the upgrade of infrastructure of the market of housing and communal services:

- shortage of financial resources for the state. By different estimates, radical upgrade of housing-and-public utilities requires from 50 to 100 billion rubles;

- deficit of investment resources for the development of private infrastructure.

- growth of the need for services of the state.

The private equity can act as the sources of financing for the upgrade of municipal infrastructure (joint-stock finance; bank loan; bonds), and also do the public finances (the percent of public financing is inversely proportional a consumer capability of potential users of infrastructure and services).

In the investment model of financing of the upgrade of infrastructure it is necessary to distinguish two levels: the target budget financing and the mechanisms of attraction of nonstate means.

The main aspect in reforming of the model of the upgrade of municipal infrastructure is to create the mechanism of connection of functions of the state on forming of policy in the market and commercial functions of business

The housing-and-public utilities treat the most perspective spheres for implementation of tools of public-and-private partnership, on the equal basis with the power industry, as well as social and transport infrastructure (Table 2).

Table 2. Industry structure of use of public-and-private partnership in the countries.

\begin{tabular}{|c|c|c|c|c|c|c|c|c|c|c|}
\hline $\begin{array}{l}\text { 音 } \\
\text { ठ }\end{array}$ & 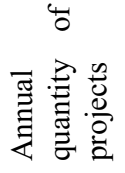 & 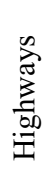 & 离 & 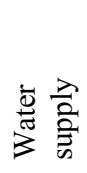 & $\begin{array}{l}0 \\
\frac{0}{y} \\
\tilde{n} \\
3\end{array}$ & 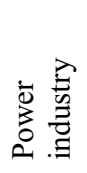 & 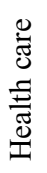 & 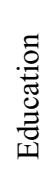 & 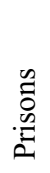 & $\begin{array}{l}\frac{n}{0} \\
\frac{0}{2}\end{array}$ \\
\hline Australia & $10-20$ & + & + & + & & & + & & + & \\
\hline Belgium & $5-10$ & + & + & + & + & & + & + & & \\
\hline Canada & $>100$ & + & + & + & + & & & & & \\
\hline Finland & $0-5$ & + & + & & & + & & & & \\
\hline France & $>100$ & + & + & + & & + & & & & \\
\hline Germany & $0-5$ & + & + & + & + & & & & & \\
\hline England & $>100$ & + & + & + & + & & + & + & + & + \\
\hline Japan & $0-5$ & & & & + & & & & & \\
\hline Italy & $0-5$ & + & + & & + & & & & & \\
\hline $\begin{array}{l}\text { South } \\
\text { Africa }\end{array}$ & $5-10$ & + & & + & & & + & + & + & \\
\hline Sweden & $0-5$ & & + & & & & & & & \\
\hline Greece & $0-5$ & + & + & & & + & + & & & + \\
\hline
\end{tabular}




\section{Conclusions}

For the successful use of the public-and-private scheme in the market of housing and communal services it is necessary to provide the following conditions: certain legislation; simplicity and transparency of procedures; equity structure of the distribution of risks and benefits; social and commercial benefits of the projects; special attention paid to the expected revenue stream; public sector acting as the initiator of projects.

Respect for interests of the municipal and housing organizations is the basic moment for the goal achievement, the housing and communal services pursued by the state during carrying out adjustment policy of the market. the creation at the municipal level of effective system of motivation for the operating municipal municipal entities can really turn the provision to the direction of the increase in the efficiency of their activities.

The state is to offer businessmen several options of return of the invested means $[7,8]$. First of all, that is the payment of the investor's investments by the authorities with installments. In this case the return of investments to the entrepreneur (or private company) is performed at the expense of the tax revenues of the state taking into account percent which makes the reservation by the parties in their contract previously.

Secondly, the private investor can return the investments to the project of public-andprivate partnership due to independent collection of payments from consumers of service.

At last there is the mixed option when the part of the investor's expenses is covered by the tax revenues in the state budget, and the rest - due to payment by consumers of services. That means that anyway the consumer of service pays for the infrastructure facility as the result, as he or she is a taxpayer.

The conditions for consumers of housing and communal services are the following:

1. preserving stable deliveries;

2. acceptable price level in the long-term period;

3. minimization of negative consequences for the financial stability of the entities.

Two basic principles of public-and-private partnership in the housing sector can be formulated:

1. risk minimization of interruptions in rendering housing and communal services and uncontrollable growth of rates when ensuring extremely careful, weighed and gradual approach to reforming of housing and public utilities;

2. ensuring system approach to reforming of the natural monopolies based on the single special authority for the purpose of ensuring coherence, coordination and control of implementations of actions for implementation of reforms. Parallelism of the implementation of reforms of all the natural monopolies is required as the economic situation and tariff policy in each of these industries directly influence the allied industries.

3. possibility of forming of the system of direct long-term contracts among consumers and housing-and-communal services producers as market component.

4. taking into account the need of adequate change of the mode of regulation.

5. creation of favorable conditions for the investment attraction.

Now the public-and-private partnership in the housing-and-municipal sector of the economy at the legislative level is worked out insufficiently. In spite of the fact that the law on concessions is adopted, its use in economy of Russia, including, in reform of housing and public utilities is being late. One of the constraining moments is the continuing differentiation of powers of authorities at all the levels, that is working off of the status and powers of the concessor continues. Difficulties of the concessionary agreement are connected with the fact that in the adopted law "On Concessionary Agreements" there were reticences and uncertainty. For example, the legislator refused administrative regulations on 
protection of interests of the third parties, on the one hand, and on the other hand established some liabilities of the concessionary to them.

Resuming international and domestic experience of the transformations in the market of housing-and-public facilities and housing-and-communal services, we can prove that ensuring investment appeal of the long-term contracts by means of public-and-private partnership is the solution of problems of housing-and-public facilities. Tendencies on strengthening of investment and innovative appeal of housing-and-communal services and infrastructure, housing-and-communal services, are the sinergetic for the institutional transformations, performed by the state and public-and-private partnerships will be able to remove effectively meanwhile the unattractive sector of the economy from crisis.

\section{References}

1. UNEP - UNESCO conference on human habitation (Habitat, Vancouver, 1976)

2. E.M. Akimova, E.M. Stein, Y.S. Prokhorova, Journal of Advanced Research in Law and Economics 6, 472-487 (2015)

3. N.G. Verstina, T.N. Kisel, N.N. Taskaeva, E.M. Akimova, A.V. Fedosina, International Journal of Applied Engineering Research 10, 41156-41163 (2015)

4. E.Y. Chibisova, Journal of International Scientific Publications: Economy \& Business 2, 600 (2015)

5. E.Yu. Chibisova, Assessment of financial efficiency of the investment project (Textbook, Moscow, 2004)

6. A. Mottaeva, MATEC Web of Conferences 73, 07020 (2016)

7. I. Polyakova, E. Vasilyeva, Procedia Engineering 165, 1380-1387 (2016)

8. I.S. Polyakova, E.Yu. Chibisova, Journal of economy and entrepreneurship 5(70), 579$582(2016)$

9. V.S. Morozov, N.N. Taskaeva, Man in India 96, 2009-2023 (2016)

10. E. Stein, N. Taskaeva, E. Chibisova, Procedia Engineering 165, 1410-1416 (2016)

11. O.B. Skripnik, S.A. Lochan, D.S. Petrosyan, Challenges of modern Russia: the rational use of managerial potential of national and regional economy (KNORUS, Moscow, 2016)

12. O.B. Skrypnik, D.S. Petrosyan, Auditing and financial analyses 6, 363-368 (2016)

13. A. Gorodetskiy, Matters of economics 10, 119 (2000)

14. V.V. Buzyrev, V.S. Chekalin, Economy of the housing sphere (INFRA-M, Moscow, 2016)

15. http://www.gks.ru/wps/wcm/connect/on

16. S.Kanyukova, N.Vatin, D.Leybman, T.Sazonova, Procedia Engineering, 165, 1918 1924, (2016),DOI 10.1016/j.proeng.2016.11.942

17. An.B. Mottaeva, As.B. Mottaeva, International Journal of Applied Engineering Research 11, 6808-6816 (2016)

18. M. Jocovic, B. Melovic, N. Vatin, V. Murgul, Applied Mechanics and Materials, 678, 644-647 (2014) 